\title{
On The Extent, Growth, and Efficiency Consequences of State Business Tax Planning
}

\author{
Donald Bruce, ${ }^{1}$ John Deskins, ${ }^{2}$ and William F. Fox ${ }^{1}$ \\ ${ }^{1}$ University of Tennessee and ${ }^{2}$ Creighton University
}

June 2005

\begin{abstract}
Our focus in this essay is on the extent to which tax planning in response to variations in state tax policy has affected state corporate income tax bases and revenues. Tax planning is defined as a broad set of actions undertaken by firms to reduce their tax liability. Financial or accounting tax planning is contrasted with what we refer to as locational distortions, in which firms move physical operations to avoid higher tax liabilities. Results from a fixed effects instrumental variables regression model using a 1985-2001 panel of state-level data provide highly suggestive evidence that tax planning activity significantly diminishes taxable corporate profits in high tax states. Specifically, we find that state corporate income tax bases decline by nearly 7 percent following a onepercentage-point increase in the top marginal corporate income tax rate, controlling for locational distortions. We also find that throwback rules are usually ineffective in restoring corporate income tax bases while combined reporting requirements are often effective. Further analysis indicates that tax planning has not diminished the locational distortions of tax policy.
\end{abstract}

Corresponding Address: John Deskins

Economics \& Finance Department

College of Business Administration

Creighton University

2500 California Plaza

Omaha, NE 68178

Phone: 402.280.2612

Email: johndeskins@,creighton.edu.

The authors thank Dhammika Dharmapala, Brian Hill, LeAnn Luna, Matthew Murray, Michael McKee, Kenneth Anderson, and participants in the University of Tennessee Department of Economics Seminar Series and the 2004 National Tax Association Annual Conference for insightful comments on an earlier draft. The authors also thank Bill Gentry, Charles McLure, Joel Slemrod and participants in the OTPR corporate tax conference for many helpful comments and suggestions.

(C)2005 by Donald Bruce, John Deskins, and William F. Fox. All rights reserved. Short sections of text, not to exceed two paragraphs, may be quoted without explicit permission provided that full credit, including (C) notice, is given to the source. 


\section{Introduction}

Traditionally, much of the literature on state corporate taxation has focused on how taxes affect the location of economic activity (see Wasylenko, 1997). A perpetual concern among policymakers is that higher tax rates or broader tax bases will retard regional economic development. In contrast, some recent research has begun to focus more on tax planning, or how firms expand after-tax profits by adjusting to tax policy through financial arrangements within related firms. Interest in tax planning among businesses is evidenced by the fact that each of the Big Four accounting firms and many banks maintain specific groups to deal exclusively with aiding firms in making arrangements to reduce their tax liability.

Tax planning is defined here as a broad set of tax avoidance and evasion schemes that affect only financial arrangements of firms. Tax planning is contrasted with strategies in which firms move physical operations to avoid higher taxes - herein termed locational distortions of tax policy. ${ }^{1}$ Firms may also respond to corporate taxation by altering the input mix or production technology, though no attempt is made here to measure the implications of this third effect. Tax planning exploits differences in state tax policies and often involves sophisticated arrangements wherein firms create one or more subsidiaries for the purpose of shifting income from high to lower tax jurisdictions. Tax planning strategies are often legal, but some may fall into a legally gray area or even

\footnotetext{
${ }^{1}$ Note that location distortions need not be restricted to the movement of an entire firm. Many location distortions may involve marginal changes in economic activity, such as when a firm makes decisions to expand output by employing excess capacity at facilities located in low tax rather than high tax areas.
} 
be blatantly illegal methods of tax evasion such as underreporting taxable income or overstating tax deductions. ${ }^{2}$

Policymakers' uneasiness surrounding increases in the use of tax planning techniques is grounded in these techniques' potential contribution to the decline of state corporate income tax bases. State corporate income tax revenues as a share of corporate profits fell by about one-third from 1989 to 2002 (controlling for rate changes), and some have asserted that tax planning is a significant contributor to this decline (Fox and Luna, 2002). ${ }^{3}$ Policymakers' concerns are evidenced by the fact that, since 2002, as many as 18 states have considered adding or modifying a combined reporting requirement with the intention of retarding tax planning activities (Houghton, Hogroian, and Weinreb, 2004). Other potential problems include lost neutrality when only a subset of firms is able to use tax planning to minimize taxes and increases in compliance and administrative costs associated with implementing tax planning practices.

If one is only concerned with the revenue consequences of tax planning, then the growing literature on the elasticity of taxable income is perhaps most relevant. ${ }^{4}$ Specifically, locational distortions, tax planning, and other responses potentially change a state's corporate income tax base, so an analysis of the overall elasticity of reported taxable corporate income would give policy makers a good picture of the combined problem from a revenue perspective. However, the purpose of this paper is to isolate tax planning effects from locational distortions in a broader consideration of economic

\footnotetext{
${ }^{2}$ An aggregation of tax avoidance, tax evasion, and ambiguous practices differs from traditional analysis but is consistent with recent research. See Slemrod (2004) who refers to these actions as "tax selfishness." One advantage of this aggregation is the ability to avoid categorizing legally ambiguous practices along the gray area between evasion and avoidance.

${ }^{3}$ Other likely determinants of the tax base erosion are reductions in the federal corporate income tax base (to which essentially every state CIT base is coupled) and state policy decisions such as concessions for economic development purposes.

${ }^{4}$ See Slemrod (1998) and Slemrod (2001) for a general discussion.
} 
efficiency. The extent to which tax planning might be substituting for locational effects is important, even though the combined revenue effects might be slight.

Unfortunately, the efficiency consequences of tax planning alone cannot be determined a priori. For example, prior to the adoption of tax planning strategies, firms might have moved real activity in response to tax policy, creating an inefficient allocation of resources. Tax planning strategies might allow firms to respond to tax policy through structural changes within the firm, removing the inefficiency from repositioning operations. Even if tax planning and locational distortions have identical effects on reported taxable income (and revenues), greater tax planning and correspondingly less locational distortions might have a net positive effect on overall economic efficiency.

Some also would assert that tax planning could be efficiency-enhancing when viewed within a Leviathan framework (i.e., it helps to constrain a government that is too large). On the other hand, tax planning may retard efficiency if it ignites a "race to the bottom" that yields tax rates on mobile capital below an efficient level, resulting in an economy that is too capital intensive (Inman and Rubinfeld, 1996). Further, overall efficiency changes depend on other factors such as administrative and compliance costs (which could potentially be very large) and, in a revenue neutral framework, on the alternative revenue sources used to replace declining corporate tax revenues.

The degree to which tax planning has eroded state tax bases is yet to be empirically tested with a significant degree of rigor. It remains to be seen whether accounts of tax planning are anecdotal and isolated or whether tax planning has significantly reduced tax revenues. Indeed, as evidenced by the Associated Industries of Massachusetts (2004), a consensus regarding the extent of tax planning is elusive. Fully 
informed tax policy decision-making requires a greater understanding of the causes, effects and extent of tax planning.

The purpose of this essay is to determine the extent to which tax planning in response to tax policy differences across U.S. states has lowered state corporate income tax revenues. This effect cannot be measured directly but will be accomplished indirectly by examining relationships between several state tax policy parameters and state corporate income tax bases. More specifically, evidence of the impact of tax planning can be inferred from an econometric model that examines the effects of tax structure variables on the corporate income tax base while holding state economic activity constant. This study also assesses the degree to which the effect of such activities on corporate income tax bases has changed over time. Further, the analysis allows us to examine whether the effectiveness of state efforts to restore corporate income tax bases (i.e., combined reporting requirements and throwback rules) are effective.

This study proceeds as follows. Section 2 reviews the relevant literature. Section 3 presents a more in-depth discussion of several tax planning strategies. Section 4 details the empirical strategy and the data that are used. Section 5 presents a discussion of the results, and Section 6 offers a conclusion. Results indicate that tax planning in response to state tax policy differences significantly diminishes state corporate income tax bases in higher tax states. In addition, the evidence suggests that combined reporting requirements are frequently effective in partially restoring state corporate income tax bases while throwback rules are not. Results do not indicate that tax planning has diminished the location distortions of tax policy between 1985 and 2001. 


\section{Existing Literature}

No studies have been identified that specifically measure the extent to which tax planning has eroded state tax bases. Fox and Luna (2002) review state corporate income tax revenue trends and assert that tax planning is a contributor to the decline of state corporate bases. They also discuss some of the methods that are intended to restore corporate income tax base erosion due to tax planning (some of which are discussed below). However, they do not specifically measure the effect of tax planning on state tax bases. $^{5}$

Mintz and Smart (2004) investigate the extent to which income shifting among affiliated companies (which constitutes one form of tax planning) affects provincial tax bases in Canada. They develop a theoretical model that finds that taxable income for multijurisdictional firms is more mobile for firms that are able to shift income between affiliated companies than for those that are not. Their model also predicts that the responsiveness of real investment to tax rate differentials is reduced by the possibility of income shifting. Then, using administrative tax records for businesses operating in Canadian provinces, they test their hypothesis by estimating and comparing taxable income elasticities between firms that are able to engage in income shifting to firms that are not, and indeed find that the elasticity of taxable income is much higher for firms that are able to shift income.

Two other areas of literature are relevant here. The first is literature on the effects of tax policy on location, or how tax policy affects the location of the physical operations of firms. This large literature represents, in large part, the traditional treatment of the effects of tax policy on business. This literature is important to this study because, (1) as

\footnotetext{
${ }^{5}$ Also see Mazerov (2003) and Schiller (2002).
} 
previously stated, it may be possible that tax planning has reduced location distortions and (2) the methods below provide further information as to the effects of tax policy on the location of economic activity. The literature on federal tax planning, which has likely grown significantly over the past decade or so, is also relevant ${ }^{6}$ since nearly every state begins its determination of profits with the federal definition. In addition, the degree to which firms pursue tax planning at the federal level may be a signal of the intensity of planning at the state level.

\section{Location Effects of Tax Policy.}

The literature on the effects of tax policy on the location of economic activity is vast, in part due to the great emphasis policymakers place on structuring tax policy to be conducive to economic development. Fortunately, Wasylenko (1997) examined over 75 studies in a review of this literature. ${ }^{7}$ What follows is a brief overview of his review. A portion of the methodology below aligns with the standards of this literature.

Wasylenko begins with a review of issues associated with the design and estimation of economic development as a function of tax policy. Most studies are based on a profit or cost function that determines the profitability of locating in a particular region. The most common measures used to capture economic activity are employment, income, investment, or business location. Explanatory variables usually include measures of input costs, such as wages and energy prices; proxies of market size, such as population, median income, or unionization; and various measures of tax policy. The most common tax policy measures are statutory tax rates and tax revenues relative to

\footnotetext{
${ }^{6}$ See Bankman (1999) for example.

${ }^{7}$ See also Bartik (1991 and 1994).
} 
some measure of income or population. Most studies fail to incorporate more detailed elements of tax structures such as incentives for economic development.

According to Wasylenko, the general conclusion of the literature on the interregional effects of tax policy is that tax policy is a statistically significant determinant of economic activity. However, the magnitudes (and even direction) of the effects of tax policy on economic development are scattered. Wasylenko reports a wide range of tax elasticities, from -1.54 to 0.54 , that depend primarily on data used for the dependent variable (particularly micro- versus aggregate-level data), methodology, and time period of analysis. However, the median tax elasticity in each of the dependent variable categories is negative and generally small. For example, studies that specify gross state product as the dependent variable (most relevant to the current study as discussed below) report a median tax elasticity of -0.07 . That is, given a 1-percent increase in some tax parameter, gross state product declines by only 0.07 percent. Federal Tax Planning.

Federal concern about tax planning is evidenced by the U.S. Department of the Treasury (1999), which expresses significant unease with the use of corporate tax sheltering (similar to the tax planning definition used here) and represents an attempt to design better strategies to combat such practices. The study cites several potential problems with tax sheltering such as revenue losses, disrespect for the tax system, increased complexity, and the cost to firms of pursuing such activities. The Internal Revenue Service (2003) estimated that losses from abusive tax shelters amounted to $\$ 14.5$ to $\$ 18.4$ billion in 1998 . The loss from sheltering amounts to between 7 and 9 percent of the $\$ 204.2$ billion in corporate tax revenues. Following Slemrod (2004), if the 
average of this span is added to a recent estimate of corporate tax evasion of $\$ 53.0$ billion (U.S. General Accounting Office, 1998), abusive tax sheltering combined with evasion amounted to 26.1 percent of corporate tax receipts in $1998 .^{8}$

A few studies have examined more closely the causes of corporate tax sheltering and the policies with which it is most closely associated. Desai (2002) studies federal tax sheltering by using simulations to examine the growing divergence between corporate book income and taxable income. He finds that over half of the difference between book and taxable income in 1998 is due to differences in the treatment of depreciation, the reporting of foreign source income, and the shift from salaries to stock options as forms of employee compensation. Desai also finds evidence that the relationship between book and tax income has become much less stable over the past few years, indicating increasing tax sheltering activity. Desai and Dharmapala (2004) develop and test a model that explains how incentive compensation for management relates to the degree to which firms pursue tax sheltering strategies. Although their theoretical model yields ambiguous results, their empirical findings indicate that increases in incentive compensation lead to less tax sheltering activity. Rego (2003) finds that economies of scale exist in tax planning, i.e., larger and more profitable multinational firms are better able to reduce their income tax liability through tax planning.

A highly publicized form of tax planning at the federal level involves corporate inversions, or when a corporation with a foreign subsidiary (usually in a low or no tax country) inverts its structure such that the foreign subsidiary becomes the parent company and the U.S. firm becomes the subsidiary. This tactic generally allows the corporation to

\footnotetext{
${ }^{8}$ See Mackie (2000) for a discussion of the problems of using average tax rates to examine the effects of tax sheltering.
} 
reduce its tax liability on its foreign income and also to hold pre-tax profits until earnings are repatriated to the U.S. Desai and Hines (2002) analyze the determinants of inversions and find that firms are more likely to invert if they are larger and more heavily leveraged and if they have more overseas assets and operate in low-tax foreign countries.

Gentry and Hubbard (1998, p.193) discuss three general forms of tax planning under the current federal corporate income tax: "discouraging incorporation, encouraging borrowing, and altering the timing of transactions." They analyze how fundamental tax reform in the form of either (1) integrating the personal and corporate systems or (2) moving from the current income tax to a pure consumption tax would alleviate these tax planning incentives. They conclude that both types of reforms can significantly reduce the incentives to adopt these forms of tax planning. ${ }^{9}$

\section{How Does State Tax Planning Work?}

Firms employ numerous tax planning strategies to reduce their tax burden. An exhaustive review is impossible because known strategies are numerous and many strategies are likely unknown to tax analysts. Some forms of tax planning include: ${ }^{10}$

(1) Reclassifying business income as non-business income,

(2) Exploiting P.L. 86-272,

(3) Using transfer pricing to shift income from high tax to low tax jurisdictions,

(4) Employing passive investment companies, and

(5) Using single member limited liability companies (LLC) to shift income out of state.

\footnotetext{
${ }^{9}$ See Hines (2002) for a discussion of how governments respond to the adoption of tax avoidance strategies.

${ }^{10}$ See Luna (2004) for discussion of state corporate tax planning.
} 
Many firms have altered the characterization of business and non-business income to reduce tax liability. The distinction is important because only business income is apportionable while non-business income is allocated to the state in which it was earned. Therefore, a firm can reduce its tax liability by classifying some income as non-business income where possible and shifting it to a low or no-tax state.

Congress passed P.L. 86-272 as a temporary measure to limit state efforts to tax multistate corporations while the best means of taxing the firms was being studied. The temporary legislation remains in place decades later. P.L. 86-272 precludes a state from levying tax on a firm whose only linkage with the state is the solicitation of sales of tangible personal property. Thus, companies can avoid tax through the creation of "nowhere income" when they sell into states where they have no presence other than solicitation, since the destination state cannot attribute the sales for corporate tax purposes and the origin state generally does not attribute the sales for corporate tax purposes.

Manipulating transfer prices is a common type of tax planning. For example, consider a firm that is headquartered in Delaware and has two wholly owned subsidiaries, a retailer in Montana and a wholesaler in Wyoming. An increase in the price that the Wyoming firm charges the Montana firm shifts profits from Montana to Wyoming. This transaction will lower overall tax liability as long as Wyoming's tax rate is lower than Montana's (Wyoming does not impose a corporate income tax), and Montana does not impose a combined reporting requirement (see below).

The fourth group of tax planning practices involves the creation of a passive investment company (PIC). This strategy often exploits the tax structure of either 
Nevada, which does not tax corporations, or Delaware, which does not tax income from intangible assets, but can be effective in other circumstances as well. Perhaps the most famous example is with Toys $Я$ Us and its subsidiary Geoffrey, Inc. Toys Я Us created Geoffrey, Inc. in Delaware to house the Toys Я Us trademark. Geoffrey, Inc. only had physical presence in Delaware. Toys $Я$ Us stores across the states pay royalties to Geoffrey, Inc. and transfer income to Delaware, effectively eliminating the income from state tax bases. Numerous corporations have duplicated this practice. South Carolina challenged the use of Geoffrey ${ }^{11}$ and prevailed, but some states have lost similar cases and other states fail to pursue income shifted through PICs (at least in part because of state's corporate tax legislation). Further, states have the often daunting task of identifying firms that are employing PIC strategies.

Lastly, single member limited liability companies (LLCs) can allow firms to shift income to the state where the member is located (see Fox and Luna, forthcoming). At the end of the 1980s, only two states permitted the LLC structure, but by the end of 1997 all states had enacted LLC legislation and all but Massachusetts permit single member LLCs. The simplest way for a corporation to use LLCs to avoid taxes is to create a single member LLC to house its operating company for a particular state and to own this LLC with a Delaware corporation that does not otherwise have nexus in the state. Income earned in the LLC state flows through to the Delaware member without tax unless the corporate tax law is changed. Delaware does not tax a firm that only administers an intangible investment, and interest in an LLC is considered an intangible. This arrangement effectively removes all of the operating firm's profits from state taxation unless the state where the LLC is located imposes an entity level tax on LLCs.

\footnotetext{
${ }^{11}$ Geoffrey, Inc. v. South Carolina Tax Commission, 114 S. Ct. 50 (1993).
} 


\section{$\underline{\text { State Strategies to Offset Revenue Losses Arising from Tax Planning. }}$}

States use a variety of strategies to lessen the effects of tax planning, several of which are reviewed here. Combined reporting requirements can at least partially restore CIT bases by precluding some tax planning strategies based on transfer pricing, such as the use of PICs. Combined reporting requires firms that are part of a unitary group to file a single corporate income tax return and thereby eliminates many of the effects of intragroup transactions. ${ }^{12}$ Combined reporting can only partially restore tax bases (see Fox and Luna, 2002, for a discussion). ${ }^{13}$ For example, foreign corporations are seldom included in the combined report, meaning a foreign PIC can help shift income. Also, only the unitary group can be required to file a combined return. ${ }^{14}$ Fourteen states imposed combined reporting in 2001 (five of those 14 states added the requirement during the timeframe of this analysis). ${ }^{15}$

States employ several other strategies in efforts to lessen the effects of PICs and transfer pricing strategies, though these should generally be less effective than combined reporting. For example, a number of states disallow deductions for payments to PICs and require the in-state firm to addback the expenses. Other states have argued that certain PICs have no economic substance and that the payments should be disallowed. Still

\footnotetext{
${ }^{12}$ One firm in the unitary group is designated to file the return on behalf of all members of the group. Some states require all firms that are part of the unitary group to be combined and other states only require those firms that are part of the unitary group and that individually have nexus in the state to file as part of the combined group.

${ }^{13}$ Combined reporting does not always lessen the capacity for tax planning, as evidenced by the frequent use of California, a combined reporting state, as situs for PICs. Firms that have nexus in California and sell into separate reporting states are not disadvantaged by locating their PIC in California to shift income from the separate reporting states to the PIC in California. This practice does not alter the firm's California taxable income since this is determined by apportionment.

${ }^{14}$ Also, combined reporting legislation in some states, such as the recently enacted legislation in Kentucky, only includes companies that individually have nexus in the state in the combined group.

${ }^{15}$ See also McIntyre, Mines, and Pomp (2001).
} 
other states have argued that the out-of-state PIC has nexus by virtue of licensing intangible property to an in-state corporation. ${ }^{16}$

A number of states use throwback rules to eliminate the nowhere income that arises because of P.L. 86-272. Slightly over half of corporate income taxing states (24 out of 44) imposed throwback rules in 2001 (six states either added or removed this rule during the timeframe of this analysis). Throwback rules require corporations to include sales in the numerator of the origin state in cases where the sale cannot be or is not included in the numerator of the destination state. This can lessen the effectiveness of tax planning strategies that attempt to shift income to states where corporations do not have nexus, though firms may easily plan around the throwback rules by selling from nonthrowback rule states (see Fox, Luna, and Murray, 2005). Indeed, throwback rules are a form of origin-based taxation and give firms an incentive to locate sales in states that do not impose such rules.

\section{Empirical Design and Data}

The primary hypothesis in this study is that cross-state differences in corporate tax policies have led to tax planning that has significantly lowered state corporate income tax bases. The effect of tax planning on tax bases cannot be measured directly but can be tested in the following way. A state's total CIT base is determined by three factors: (1) a set of state-determined institutional parameters that define taxable income, (2) the magnitude of economic activity in the state that is taxed under the CIT structure, and (3) the ability of firms to make financial or accounting adjustments to lower their tax liability. The third determinant of the CIT base is tax planning - the myriad ways in

\footnotetext{
${ }^{16}$ See Tax Management Multistate Tax Report (2004) for a discussion.
} 
which firms adjust and restructure to lower tax liabilities. Tax planning to reduce taxable profits may be spurred by any tax policy change that raises the effective tax rate that firms face, by differences in tax structures between states, or by changes in state law that make planning easier. ${ }^{17}$

State tax policy can affect firm behavior along a number of different margins, some of which entail tax planning responses and others of which change real behavior. We seek to separate these two types of responses by estimating the regression model that explains state CIT bases as a function of the set of government parameters that define the CIT base, Gross State Product (GSP) and variables that change the effective tax rate that firms face. GSP is included in the model to account for the effect that tax structures have on tax bases through changes in the real behavior of firms, with the goal being to isolate the effects of tax planning by separating out real effects.

Firms can make two real economic responses to the higher relative price of capital caused by an increase in the effective corporate tax rate. They can relocate production to lower-cost-of-capital states, or they can change the capital/labor ratio (either within the existing technology or by using a new technology) used within the taxing state. Changes in the location of production are accounted for through GSP and are isolated from tax planning. Changes in the capital/labor ratio are accounted for through GSP to the extent that firms reduce output as they alter relative input use. That said, substitution of labor for capital will presumably also reduce firms' before-tax profits, and this will get

\footnotetext{
${ }^{17}$ Of course, other effects complicate this picture and render the relationship between higher tax structures and tax planning theoretically ambiguous. See Crocker and Slemrod (2004) and Slemrod (2004) for recent models of corporate income tax evasion.
} 
reflected in a lower CIT base. The extent of tax planning is overstated in the empirical results to the extent that a lower tax base results from firms' changes in their input mix. ${ }^{18}$

A foremost econometric issue in this context is the potential endogeneity of GSP in explaining the CIT base since changes in the CIT base could also affect state economic activity. Therefore, we use both a standard model that does not control for endogeneity as well as a two-stage instrumental variables regression model that estimates GSP in the first stage and CIT base in the second. Of course, the two-stage model requires at least one instrumental variable in the GSP equation that does not have an independent effect on the CIT base. Technical details are discussed below.

A second hypothesis is that tax planning has begun to substitute for the location distortions of tax policy. More specifically, firms may be increasingly able to avoid higher taxes simply by engaging in tax planning strategies rather than actually moving physical operations to lower tax jurisdictions. This hypothesis can be tested by examining how the effect of the CIT rate on its base (holding GSP constant) and on GSP differs over time. This approach is accomplished in the regression framework by including an interaction between the CIT rate and a time variable. If tax planning activity is rising and if tax planning and location responses are substitutes, the CIT rate (and other tax policy instruments) is of waning importance over time in determining state economic activity. The CIT rate would also have a growing effect on its base over time if tax planning were becoming more prevalent. Both of these hypotheses, that real investment

\footnotetext{
${ }^{18}$ The same can be said about other distortions, such as those regarding debt and equity policies, organizational form, and incorporation decisions. To the extent that distortions along these margins reduce the CIT base but are not accompanied by output changes, their influence will be part of our estimated tax planning effects.
} 
would be less responsive, and that taxable income would be more responsive to tax policy differentials, are consistent with the theoretical model of Mintz and Smart (2004). Model Structure and Variable Description.

We employ a panel of data from all 50 U.S. states for years 1985 through 2001. The specific structure of the regression equations and the variables included in them are defined below.

Economic Activity and Corporate Income Tax Base Measures. Non-government gross state product (GSP) is used to measure economic activity. Government production is excluded because it is potentially not subject to corporate taxation.

The corporate income tax base is approximated by dividing corporate income tax collections by the highest marginal state corporate income tax rate for those states with a corporate income tax. ${ }^{19}$ This method suffers from measurement error given that a few states have progressive corporate income tax schedules. However, the consequences of this error are likely to be minor for two reasons. First, the majority of states (31 out of 44 that taxed corporate income in 2001) have a single rate. Second, in the remaining 13 states that have progressive corporate income tax schedules, the threshold for the top bracket is relatively low such that the majority of income falls into the top bracket. ${ }^{20}$

The corporate income tax base is estimated for the six states without a corporate income tax by regressing a measure of the federal corporate income tax base by state (Internal Revenue Service, various years) on state CIT bases using only data for states

\footnotetext{
${ }^{19}$ Nevada and Wyoming have no broad business tax. Michigan imposes a single business tax (sometimes described as a business activities tax or value added tax). Texas imposes a franchise tax on earned surplus. South Dakota imposes a corporate income tax on banks. Washington imposes a gross receipts tax termed the business and occupations tax. (Federation of Tax Administrators, 2004) Michigan, Texas, South Dakota, and Washington are treated as if they have no CIT whatsoever.

${ }^{20}$ Additionally, this over-estimate of the CIT base is at least partially offset by an underestimate due to our lack of consideration of CIT credits in the base calculation.
} 
with a CIT. The parameter estimates from this model are then applied to obtain predicted values for CIT bases for states without CITs. ${ }^{21}$ It is important to include these states in the analysis to allow for the possibility that firms consider non-CIT states in their tax planning decisions.

Tax Rates. The top marginal CIT rate is often the focal point of public attention surrounding business taxation because high rates could distort location distortions or justify the adoption of costlier and more effective tax planning techniques. The omission of the CIT rates of lower brackets leads to specification error, but the error is relatively unimportant for the same reasons offered above in the context of using the top marginal rate in calculating corporate income tax bases. ${ }^{22}$

Tax planning or real economic effects could be encouraged by any parameter that affects the overall tax burden firms face, not just parameters directly related to the corporate income tax. The state general sales tax rate is included because it represents the largest component of the overall state tax liability of many firms since it is imposed on the sales value of many business-to-business transactions (Cline et al., 2003a and 2003b; Cline et al., 2005). In a similar fashion, the top marginal personal income tax (PIT) rate is included. Firms may be more likely to incorporate when faced with higher

\footnotetext{
${ }^{21}$ This procedure uses a random effects regression that results in an overall R-squared of 0.72 . The federal corporate income tax base coefficient is statistically different from zero at the 1 percent level. Results are omitted for brevity but are available upon request.

${ }^{22}$ Our use of the top statutory CIT rate might raise concerns about measurement error if one truly believes that the firm's effective tax rate is a more appropriate measure. However, our analysis of aggregate state data rather than individual firm data makes the use of effective tax rates less compelling. Also, we view the statutory rate as an important policy signal at the aggregate level and have thus elected to include it along with most other factors in effective tax rate calculations (e.g., combined reporting and throwback rules, apportionment formula details, and other features of state CIT structures).
} 
PIT rates relative to CIT rates or closely held corporations may choose to pay less in wages to owner/operators, meaning higher PIT rates could raise the CIT base. ${ }^{23,} 24$

Corporate Tax Structure. Elements of the corporate tax structure could influence GSP and also have independent effects on CIT bases. The former is true because many of these parameters raise or lower effective corporate tax rates, which may create location distortions. The independent effects on CIT bases may occur because these variables help define the CIT base.

The first variable included in this group is the sales factor weight in the state corporate income tax apportionment formula. The apportionment formula uses a state's share of the corporation's national property, plant, and payroll to distribute the corporation's national profits to the state for tax purposes. These three factors are added together using weights that the states have been varying as economic development tools. Increasing the sales factor weight, which may entice firms (especially manufacturing firms) to expand production in a given state, has become a commonly-used instrument for attracting production.

In general, for given tax rates, locating payroll and property in a state with a high sales factor weight while selling in many states will reduce tax liability compared with locating the payroll and property in a state with a low sales factor weight and higher weights on property and payroll factors (see Edmiston, 2002). States have aggressively

\footnotetext{
${ }^{23}$ There is a significant amount of variation in CIT, PIT, and sales tax rates, both between states and within states, during the timeframe of this analysis. For each of these taxes, over half of states changed the rate at least one time from 1985 to 2001.

${ }^{24}$ A corporate franchise tax may also affect the CIT base. However, we chose not to include this variable because of the difficulty of capturing corporate franchise tax rates in a usable form. The use of a simple dummy variable for states that impose a corporate franchise tax was discarded because of the very small amount of variation in the states that impose such a tax. Omission of this variable does not bias the results because the state fixed effects control for this tax and all other state-specific characteristics that are not included in the model.
} 
increased the weight on the sales factor in the formula to lessen origin-based taxation and increase destination taxation. This also tends to lessen the corporate income tax on many multistate, and presumably more mobile firms, without affecting the tax liability of domestic firms, which do not apportion income. For example, in 1990, 32 of the 44 income taxing states applied equal weight to all three factors. By 2004, only 12 states applied equal weight to all factors, while 23 states double-weighted the sales factor (a 50 percent weight), and the remainder applied more than 50 percent weight to sales. ${ }^{25}$

The apportionment formula for state corporate income taxes can be an important element in tax planning (as firms seek to exploit differences across states or across types of business structure) or location effects. For example, until Kentucky's 2005 corporate tax reform, LLCs profits were apportioned using a single factor sales formula and other corporations were apportioned using double weighted sales. Thus, the firm could lower its liability by producing inside Kentucky in its LLC and locating a sales office outside Kentucky inside a corporation to sell back into the state.

As previously stated, combined reporting requirements can be an important element of state CIT structures, and are thus included to help explain state CIT bases. Combined reporting requirements could reduce economic activity in a state by driving away firms if such requirements effectively raise the CIT burden by disallowing some planning opportunities. Combined reporting is specified as a dummy variable to denote whether a state requires combined reporting. Other means of offsetting the use of PICs are not included because data are not available for a panel application. Whether a state has a throwback rule is included as a dummy variable. A throwback rule is intended to

\footnotetext{
${ }^{25}$ A significant amount of this variation occurred during the time period of this analysis. Indeed, 24 states increased their sales factor weight at least once during this time period.
} 
raise the CIT base as it narrows avoidance possibilities, but could create location distortions because it raises the origin component of the CIT. ${ }^{26}$

State legislation permitting limited liability companies (LLCs) can create tax planning opportunities and may affect economic activity across states (see Fox and Luna, 2005). The option for LLC status could affect economic activity because firms may start in or relocate to states to exploit this organizational form. The LLC structure can be preferred over the C-corporation structure because LLCs also offer limited liability, but in many cases they are treated as pass-through entities with the income taxed only under the PIT system. ${ }^{27}$ Further, LLCs are often exempt from some other corporate taxes, such as the corporate license taxes in Louisiana. This arrangement allows these firms to avoid double taxation of the CIT and PIT systems, reducing CIT bases. In addition, singlemember LLCs can erode CIT bases through the tax planning opportunities described above. This variable is specified as a dummy to denote whether states permit LLCs. Allowing corporations to deduct their federal CIT liability will directly lower state CIT bases. We include a dummy variable to denote a federal CIT liability deduction from the state CIT. This variable essentially lowers the effective CIT rate that firms face in a state and, thus, may generate locational distortions. Economic development incentive programs are inherently difficult to capture in a simple metric because of the wide variation in incentive programs offered across states. They are incorporated in this analysis via a count of the number of incentive programs that states offer. The counts are

\footnotetext{
${ }^{26}$ It should be noted that we include two of the most common and most visible policies that have been used to offset the effects of tax planning but this does not represent a comprehensive set of such variables. States use several other policies, some of which were discussed in Section 3, to lessen avoidance opportunities. However, reliable data on these policies for all states and for the time period of this analysis are difficult to obtain. We leave this to future work.

${ }^{27}$ The LLC structure also offers some advantages over S-corporations. For example, there is no limit on the number of members of an LLC whereas an S corporation is limited to 100 shareholders ( 75 before 2005).
} 
divided into the number of tax incentive programs and the number of non-tax incentive programs. Both of these counts may increase economic activity by attracting firms to a state. Tax incentive programs should lower the CIT base because states are providing tax breaks through these programs. Non-tax incentive programs may increase real economic activity as they lower business costs, although no independent effect on the tax base is expected. $^{28}$

The primary stage of the regression model is summarized below:

$$
\begin{gathered}
\text { CIT Base }_{i, t}=\beta_{0}+\beta_{1} \text { CIT Rate }_{i, t}+\beta_{2} \text { PIT Rate }_{i, t}+\beta_{3} \text { Sales Rate }_{i, t}+\beta_{4} \text { Sales } \\
\text { Factor Apportionment }_{i, t}+\beta_{5} \text { Combined Reporting }_{i, t}+\beta_{6} \text { LLC C }_{i, t}+ \\
\beta_{7} \text { Throwback Rule }_{i, t}+\beta_{8} \text { Fed CIT Deductibility }_{i, t}+\beta_{9} \text { Tax Incentives }_{i, t}+ \\
\beta_{10} \text { Non-Tax Incentives }_{i, t}+\beta_{11} \text { GSP }_{i, t}+\varepsilon_{i t}
\end{gathered}
$$

where $i$ and $t$ are state and year indices.

Instruments for GSP. As previously mentioned, GSP is likely to be endogenous with respect to the CIT base. ${ }^{29}$ The first-stage GSP instrumenting equation includes all of the explanatory variables in the CIT base equation plus a set of socio-economic instrumental variables that explain GSP but do not have independent effects on CIT bases. This specification is consistent with the literature that explains the determinants of economic activity as discussed in the review of location effects of tax policy. ${ }^{30}$ Most of this literature models locational decisions by constructing profit functions (or other related functions) to determine profitability, and correspondingly, the decision to locate into a region. The literature includes variables such as measures of regional market

\footnotetext{
${ }^{28}$ See Zodrow (2003) for a discussion of tax incentives.

${ }^{29}$ To be precise, under perfect information the CIT base does not affect GSP directly, rather it is the parameters that define the base that affect GSP. However, given the complexity of CIT structures, firms may not separately consider every parameter that defines the CIT base and, under these circumstances, respond directly to the CIT base. A standard Hausman test revealed that GSP is endogenous in the CIT base equation (Hausman, 1978).

${ }^{30}$ See, for example, Wasylenko and McGuire (1985).
} 
demand, costs of producing in a particular location, and, of course, taxes. The following summarizes this (first-stage) equation:

$$
\begin{aligned}
& \mathrm{GSP}_{i, t}=\beta_{0}+\beta_{1} \text { CIT Rate }_{i, t}+\beta_{2} \text { PIT Rate }_{i, t}+\beta_{3} \text { Sales Rate }_{i, t}+\beta_{4} \text { Sales } \\
& \text { Factor Apportionment }{ }_{i, t}+\beta_{5} \text { Combined Reporting }_{i, t}+\beta_{6} \mathrm{LLC}_{i, t}+
\end{aligned}
$$

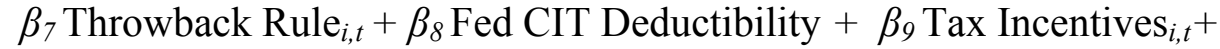

$$
\begin{aligned}
& \beta_{10} \text { Non-Tax Incentives }{ }_{i, t}+\beta_{11} \text { Population }_{i, t}+\beta_{12} \text { Median Income }_{i, t}+\beta_{13} \\
& \text { Population Density } y_{i, t}+\beta_{14} \text { Government Expenditures }_{i, t}+\beta_{15} \text { Manufacturing } \\
& \text { Wage }_{i, t}+\beta_{16} \text { Education }_{i, t}+\beta_{17} \text { Energy Price }_{i, t}+\varepsilon_{i t,} \text {, }
\end{aligned}
$$

where, as before, $\mathrm{i}$ and $\mathrm{t}$ are state and year indices.

Two measures of input costs are included. The first is the average hourly wage for manufacturing workers in a state. The second is a measure of overall energy prices in a state (including all forms of energy such as gas, electricity, etc.). State population and median income are included to control for state size and demand. Population density is included because a high population concentration may influence the ability of firms to achieve economies of operation. Total state government expenditures per capita control for government size. Government size has an ambiguous theoretical effect; firms may be more likely to locate in a state with greater expenditures per capita recognizing the associated benefits of more public services. Alternatively, they could focus on the higher taxes accompanying larger governments and choose to locate elsewhere to the extent that per capita taxes and expenditures are correlated. The percentage of a state's residents (over age 25) who hold a baccalaureate degree or higher would likely influence GSP because many firms require an educated workforce. ${ }^{31}$

\footnotetext{
${ }^{31}$ This education variable is not available for $1985-88$, so values are imputed based on the average rate of change in each state between 1980 and 1989.
} 
All regressions include state- and year-specific fixed effects to control for state and time specific factors not included in the model. ${ }^{32}$ CIT bases and GSP are entered as natural logs to control for the scaling effects from the wide variation in GSP and CIT bases between large and small states. The time period of analysis, 1985 through 2001, is advantageous in that it began just before the Tax Reform Act of 1986, which potentially affected tax planning by reducing marginal federal corporate income tax rates, thereby increasing the relative value of avoiding state business taxes from the perspective of firms. This time span also allows for broad changes across the business cycle. Appendix 1 presents summary statistics for all variables for the first and last years of the study and Appendix 2 provides variable descriptions and source notes.

\section{Results and Discussion}

This section first discusses the results from the baseline model. It then turns to a modified baseline model that includes the CIT rate interacted with other CIT structural parameters to more precisely identify the effects of these parameters. The section closes with another modification of the baseline model that considers the possibility that tax planning has replaced the location distortions of tax policy over time.

\section{Baseline Model.}

GSP Results. Table 1 presents results from the primary regression model.

Estimates from the first stage equation indicate that the top CIT rate does not have a statistically identifiable effect on private sector economic activity. However, increases in

\footnotetext{
${ }^{32}$ Note that this will influence our interpretation of the regression results, as statistical significance will be identified on the basis of changes in variables over time as well as cross-state differences. We also estimated the model using a random effects specification, but a Hausman (1978) test revealed correlations between the explanatory variables and the random effects.
} 
top PIT rates and sales tax rates are associated with lower levels of output growth. One possible explanation is that the sales tax and PIT each account for about one-third of state tax revenues (and large shares of business costs) while the corporate income tax currently generates only about six percent of state tax revenue. The magnitude of the PIT rate effect is relatively small: a one-percentage-point increase in the top PIT rate decreases GSP by only 0.6 percent. In contrast, a one-percentage-point increase in the sales tax rate lowers GSP by 3.6 percent. $^{33}$

The sales factor weight in the state CIT apportionment formula is also a statistically significant determinant of GSP. The model predicts that a sales factor weight increase from 33 percent to 50 percent would increase GSP by 1.7 percent. Deductibility of federal CIT liability from state CITs tends to reduce GSP growth, though the estimated effects are larger than seems reasonable. As variation in this factor is limited to a very small number of states, it may be picking up other influences common to those states. In addition, the number of non-tax incentive programs has a statistically distinguishable, but unexpected negative, relationship with GSP. The programs may offer lower benefits than the tax costs, so the net effect is a reduction of economic activity. Alternatively, this variable could be endogenous with gross output if more non-tax incentive programs are developed in low output states.

Some of the other control variables in the first stage of the model also deserve attention. As would be expected, states with higher population or median income growth relative to the national average have higher relative GSP growth. Interestingly, increases in state government expenditures per capita tend to yield lower GSP growth. The overall

\footnotetext{
${ }^{33}$ The sales tax effect translates into an elasticity of -0.2 . That is, a one-percent increase in the sales tax rate yields a -0.2-percent decrease in GSP (based on the average sales tax rate of 4.6 percent in 2001). This magnitude is within the range of tax elasticity estimates discussed in Wasylenko (1997).
} 
relationship between government spending and total output is not captured because the GSP measure excludes government spending; this result could simply reflect the crowding out of private output. States with higher growth in average wages for manufacturing workers have higher rates of growth in economic output. This likely suggests that more skilled workers, as evidenced by greater salaries, result in greater output. In addition, increases in a state's highly educated population are associated with higher GSP growth.

Corporate Income Tax Base Results. Results from the second stage of the model indicate that GSP is highly significant in explaining the CIT base with an estimated elasticity of 0.60 . The lack of statistical significance on the constant term in this equation, combined with the significance of GSP, indicate that the CIT base fundamentally follows from GSP, as would be expected.

A one-percentage-point increase in the top CIT rate is associated with a 6.6 percent decrease in the corporate income tax base, holding GSP and all else in the model constant. ${ }^{34}$ The relationship between the CIT rate and base is mostly attributable to tax planning activities because holding GSP constant eliminates the effect of location distortions on the base. However, effects on profitability arising from changes in the relative use of inputs can also be included in this coefficient. Further, the CIT base declines by 1.5 percent following a one-percentage-point increase in the PIT rate, again attributable to tax planning. As previously stated, when faced with higher tax rates in the PIT system, owners may be cost-justified in seeking more tax planning opportunities.

Several other tax variables are statistically significant in explaining the CIT base. Higher sales factor weights relative to the national average are associated with higher

\footnotetext{
${ }^{34}$ This translates into an elasticity of -0.44 (based on the average top CIT rate of 6.6 percent for 2001).
} 
relative CIT base growth. Changing the apportionment formula does not create any additional tax base across the 50 states, but differences in state apportionment formulas appear to allow those states with higher sales ratios to tax a greater share of the corporate tax base. The model provides no evidence that state efforts to limit tax planning are effective. The imposition of combined reporting requirements or throwback rules has no effect on CIT bases in this context. These policies receive more attention in the next section.

The model also fails to find evidence that allowing LLCs erodes the CIT base. Fox and Luna (2005) use a different CIT base measure and find that advent of LLCs lowered tax revenues, but only when the analysis is run without fixed effects for time. The result found here might also be due to a high degree of correlation between the LLC dummy and the year fixed effects. As expected, allowing the deduction of federal CIT liability reduces state CIT base growth. In addition, more tax incentive programs reduce growth in the CIT base. More non-tax incentive programs are associated with higher CIT base growth, holding GSP constant. Perhaps firms pursue tax planning strategies less aggressively when offered more non-tax incentive programs, thereby increasing the tax base.

We also present a set of results from a standard fixed effects model that does not control for the possible endogeneity bias. Here our tax policy results are largely similar to those in the instrumental variables specification, indicating that any endogeneity bias is small. Nonetheless, since a Hausman test revealed GSP endogeneity, we will continue to focus on the two-stage results. 
Several pieces of policy-relevant information can be drawn from these results. Sales and personal income tax rates have statistically significant and negative effects on economic activity in states, although the effect of the personal income tax is small. On the other hand, the corporate income tax rate does not have a significant effect on economic activity. Higher corporate income tax rates do appear to encourage tax planning, so policymakers should be aware of the large tax-planning-related base erosion that would likely follow an increase in corporate income tax rates.

\section{Baseline Model Modified to Include CIT Rate Interactions.}

Table 2 presents a set of results similar to those in Table 1 with the difference being the inclusion of (1) interactions of the top CIT rate with the sales factor weight in the CIT apportionment formula, combined reporting requirements, throwback rules, and LLC allowances and (2) the CIT apportionment formula, combined reporting, and throwback rule variables interacted with each other in each possible two-way combination. This specification allows for a more in-depth examination of the effects of these variables because it more precisely identifies how the effect of each element of CIT structure differs across policy regimes defined by the other CIT factors. This framework is especially important given that it is likely that many firms consider state tax structures from a broad perspective (i.e., rates and other policies in conjunction) rather than from a narrower perspective that only considers each element of the tax structure in isolation. We focus our discussion of Table 2 on the CIT base results, leaving a more detailed analysis of the GSP results to the reader.

Our first result of note in Table 2 is that we find no separate effect of the CIT rate on tax planning. Instead, the CIT rate only reduces the base in states that impose a 
throwback rule. More specifically, the CIT base falls by 7.1 percent for every onepercentage-point increase in the top CIT rate. Combined reporting requirements are effective in increasing CIT bases, but the effect depends on whether a throwback rule is also imposed. The CIT base increase from a combined reporting requirement is large in states without a throwback rule but falls considerably in states with throwback rules. This suggests that the throwback rule may have reaped some of the gains that could be obtained with combined reporting. Increases in the sales factor weight only increase the CIT base in states that also impose a throwback rule. This is expected since the "throwing back" of sales into a state will have a greater impact in the formula when a greater weight is applied to sales. Results do not identify a significant relationship between LLC allowances and the CIT base.

One policy implication is that combined reporting requirements aid in restoring corporate income tax bases in most cases without diminishing economic activity. Alternatively, results indicate that throwback rules often have the perverse effect of actually diminishing CIT bases.

\section{Tax Planning Over Time.}

In the third and final component of our study, we examine whether tax planning has increased over time and whether tax planning has replaced locational distortions. We use two approaches to investigate this. First, we run the baseline model while fully interacting the top CIT rate with the year fixed effects. Second, we estimate a model in which the year fixed effects are replaced with a time trend in both level and interaction 
terms. ${ }^{35}$ Results from the latter model are presented in Table 3, while similar yet more cumbersome results from the former model are omitted for brevity. ${ }^{36}$

The first goal is to understand how effects of the tax rate on the tax base differ over time, holding GSP constant. The results from these models do not identify a significant difference in the effect of the CIT rate on the CIT base over time, providing evidence that tax planning was equally prevalent throughout the period of analysis. ${ }^{37}$

If tax planning and location responses to tax policy are substitutes, the effect of the CIT rate on GSP might decline over time if firms are beginning to use financial arrangements to avoid taxes, as opposed to location responses. This question is examined in the first stage of the model. However results from this model indicate that the corporate income tax rate actually has a larger negative effect on GSP over time. A possible explanation for this puzzling result is that new technologies may enhance firms' abilities to produce remotely, by increasing firm mobility. Perhaps this effect dominates any tax planning effect. In other words, firms may have a growing ability to produce in one state and sell nationwide given the increased use of on-line shopping and better information technologies. Therefore, firms can respond more strongly to taxes because they need not be in a particular location to serve their customers. Further research is required to verify this hypothesis. All other findings of this model are similar to the baseline model with the exception of the combined reporting variable (and LLC

\footnotetext{
${ }^{35}$ The time trend takes on the values of 1 to 17 for the years 1985 through 2001, respectively.

${ }^{36}$ The only difference between the specification with year fixed effects and a year time trend is the effect of LLC allowances. In the latter model, the LLC allowance variable is positive and significant while it is not in the former. This variable is probably identifying a time effect in the time trend model given the pattern of LLC introductions.

${ }^{37}$ A third model is estimated that included a quadratic time trend and the corresponding CIT rate interaction. The coefficients on the quadratic terms are not statistically different from zero in this model, and other results are largely unchanged.
} 
allowances as noted). Here a combined reporting requirement has a positive and statistically significant effect on the CIT base.

\section{Conclusions}

In this paper an econometric model is developed to test the extent to which tax planning activities in response to differences in state business tax policies have affected state corporate income tax bases. Results strongly suggest that tax planning activity significantly diminishes taxable corporate profits in high tax states. In particular, state corporate income tax bases decline by nearly seven percent following a one-percentagepoint increase in the top corporate income tax rate, holding Gross State Product and other state policy parameters constant. More in-depth analysis provides evidence that throwback rules are not effective in restoring state corporate income tax bases in most states. This result can be interpreted as evidence that firms seek out more planning opportunities when they are cost-justified by high corporate tax rates combined with a throwback rule. In contrast, combined reporting requirements are found to be somewhat effective in restoring corporate tax bases in most cases, but their effect is lessened in states with throwback rules.

No evidence is found that the effects of tax planning on state corporate income tax bases have grown over time. In addition, findings do not indicate that tax planning activity has replaced locational responses to tax policy over the past decade and a half.

These findings are very important for policymakers to consider in designing better corporate income tax systems. First, policymakers should consider significant taxplanning-related base erosion that would likely follow an increase in the corporate 
income tax rate. Second, if policymakers decide that restoring, or at least maintaining, the corporate income tax base is desirable, evidence suggests that combined reporting requirements are often effective in partially achieving this goal. At the same time, there is no evidence that these requirements diminish economic activity in states. Next, results provide no evidence that increased tax planning activity is a contributor to the recent corporate income tax base erosion. Further research is needed to better understand the causes of this trend. Last, results indicate that the sales tax rate significantly diminishes economic activity in states while corporate income and personal income tax rates have either statistically insignificant or very small effects. 


\section{References}

Associated Industries of Massachusetts. 2004. "A Response to Proponents of Combined Reporting: Combined Reporting is Bad for Massachusetts." State Tax Notes, April 12: 135-136.

Bartik, Timothy J. 1994. "Jobs, Productivity, and Local Economic Development: What Implications Does Economic Research Have For The Role of Government?" National Tax Journal, 47(4): 847-861.

Bartik, Timothy J. 1991. "Who Benefits From State and Local Economic Development Policies?” Upjohn Institute: Kalamazoo, MI.

Bankman, Joseph. 1999. "The New Market in Corporate Tax Shelters." Tax Notes, June 21: 1775-1795.

Cline, Robert, William Fox, Thomas S. Neubig, and Andrew Phillips. 2003a. "A Closer Examination of the Total State and Local Business Tax Burden." State Tax Notes, January 27: 295-303.

Cline, Robert, William Fox, Thomas S. Neubig, and Andrew Phillips. 2003b. "Total State and Local Business Taxes: Fiscal Year 2003 Update." State Tax Notes, October 20: 205-210.

Cline, Robert, John L. Mikesell, Thomas S. Neubig, and Andrew Phillips. 2005. "Sales Taxation of Business Inputs: Existing Tax Distortions and the Consequences of Extending the Sales Tax to Business Services." State Tax Notes, February 14: 457-470.

Crocker, Keith J., and Joel Slemrod. 2004. "Corporate Tax Evasion With Agency Costs.” NBER Working Paper 10690, Cambridge, MA.

Desai, Mihir A. 2002. "The Corporate Profit Base, Tax Sheltering Activity, and the Changing Nature of Employee Compensation." NBER Working Paper 8866, Cambridge, MA.

Desai, Mihir A. and James R. Hines, Jr. 2002. "Expectations and Expatriations: Tracing the causes and Consequences of Corporate Inversions." National Tax Journal, 60(3): 409-456.

Edmiston, Kelly. 2002. "Strategic Apportionment of the State Corporate Income Tax." National Tax Journal 60(2): 239-262.

Federation of Tax Administrators (FTA). 2004. "Range of State Corporate Income Tax Rates.” Available at http://www.taxadmin.org/fta/rate/corp_inc.html. Accessed September 10. 
Fox, William F., and LeAnn Luna. 2002. "State Corporate Tax Revenue Trends:

Causes and Possible Solutions." National Tax Journal, 55(3): 491-508.

Fox, William F., and LeAnn Luna. Forthcoming. "Do LLCs Explain Declining State Corporate Tax Revenues?" Public Finance Review.

Fox, William F., LeAnn Luna, and Matthew Murray. 2005. "How Should a Subnational Corporate Income Tax on MultiState Businesses be Structured?" National Tax Journal, 58(1): 139-159.

Gentry, William M., and R. Glenn Hubbard. 1998. "Fundamental Tax Reform and Corporate Financial Policy," in Tax Policy and the Economy, James M. Poterba (ed.), v 12:191-227.

Hausman, J.A. 1978. "Specification Tests in Econometrics." Econometrica, 46:1251-1271.

Hines, James R., Jr. 2002. “On the Timeliness of Tax Reform.” NBER Working Paper 8909, Cambridge, MA.

Houghton, Kendall L., Ferdinand Hogroian, and Adam Weinreb. 2004. "Unitary/Combined Filings: Old Concept, New Focus." State Tax Notes, August 9: 457-471.

Inman, Robert P. and Daniel L. Rubinfeld. 1996. "Designing Tax Policies in Federalist Economies: An Overview." Journal of Public Economics, 60: 307334.

Internal Revenue Service. Various Years. "Annual Report: Commissioner of the Internal Revenue and the Chief Counsel for the Internal Revenue Service." Washington, D.C.

Luna, LeAnn. 2004. "Corporate Tax Avoidance Strategies and Solutions." Journal of Multi-State Taxation and Incentives, 14(2): 6-17, 46-48.

Mackie, James B., III. 2000. “The Puzzling Comeback of the Corporate Income Tax." Proceedings of the Ninety-Second Annual Conference on Taxation, 93-102. Washington, DC: National Tax Association.

Mazerov, Michael. 2003. "Closing Three Common Corporate Income Tax Loopholes Could Raise Additional Revenue For Many States." Center for Budget and Policy Priorities: Washington, DC, May 23.

McIntyre, Michael J., Paul Mines, and Richard D. Pomp. 2001. "Designing a Combined Reporting Regime for a State Corporate Income Tax: A Case Study of Louisiana." State Tax Notes, September 3. 
Mintz, Jack, and Michael Smart. 2004. "Income Shifting, Investment, and Tax Competition: Theory and Evidence from Provincial Taxation in Canada." Journal of Public Economics, 88: 1149-1168.

National Association of State Development Agencies. Various years. "Directory of Incentives for Business Investment and Development in the United States: A State-by-State Guide.” Urban Institute: Washington D.C.

Rego, Sonja Olhoft. 2003. "Tax-Avoidance Activities of U.S. Multinational Corporations." Contemporary Accounting Research, (20)4: 805-833.

Ring, Raymond J., Jr. 1999. “Consumer's Share and Producer's Share of the General Sales Tax." National Tax Journal 52(1): 79-90.

Schiller, Zach. 2002. “Ohio’s Vanishing Corporate Franchise Tax.” State Tax Notes, November 25.

Slemrod, Joel. 2004. "The Economics of Corporate Tax Selfishness." National Tax Journal, 57(4): 877-899.

Slemrod, Joel. 2001. "A General Model of the Behavioral Response to Taxation." International Tax and Public Finance 8(2): 119-128.

Slemrod, Joel. 1998. "Methodological Issues in Measuring and Interpreting Taxable Income Elasticities.” National Tax Journal 51(4): 773-788.

Tax Management Multistate Tax Report. 2004. "Holding Companies.” Volume 11(4): S65-S68.

U.S. Department of the Treasury. 1999. "The Problem of Corporate Tax Shelters." Washington, DC, July.

U.S. General Accounting Office. 2003. "Challenges Remain in Combating Abusive Tax Shelters." Testimony before the Senate Finance Committee on Finance. Washington, DC, October 21.

U.S. General Accounting Office. 1998. "IRS' Tax Gap Studies." GAP/GGD-88-66BR. Washington, DC, October 21.

Wasylenko, Michael. 1997. "Taxation and Economic Development: The State of the Economic Literature." New England Economic Review, March/April: 37-52.

Wasylenko, Michael, and Therese McGuire. 1985. "Jobs and Taxes: The Effect of Taxes on States' Employment Growth Rates.” National Tax Journal, 38(4): 497-514. 
Zodrow, George R. 2003. "Reflections on the Economic Theory of Local Tax Incentives." State Tax Notes, June 9. 
Table 1: Baseline Model

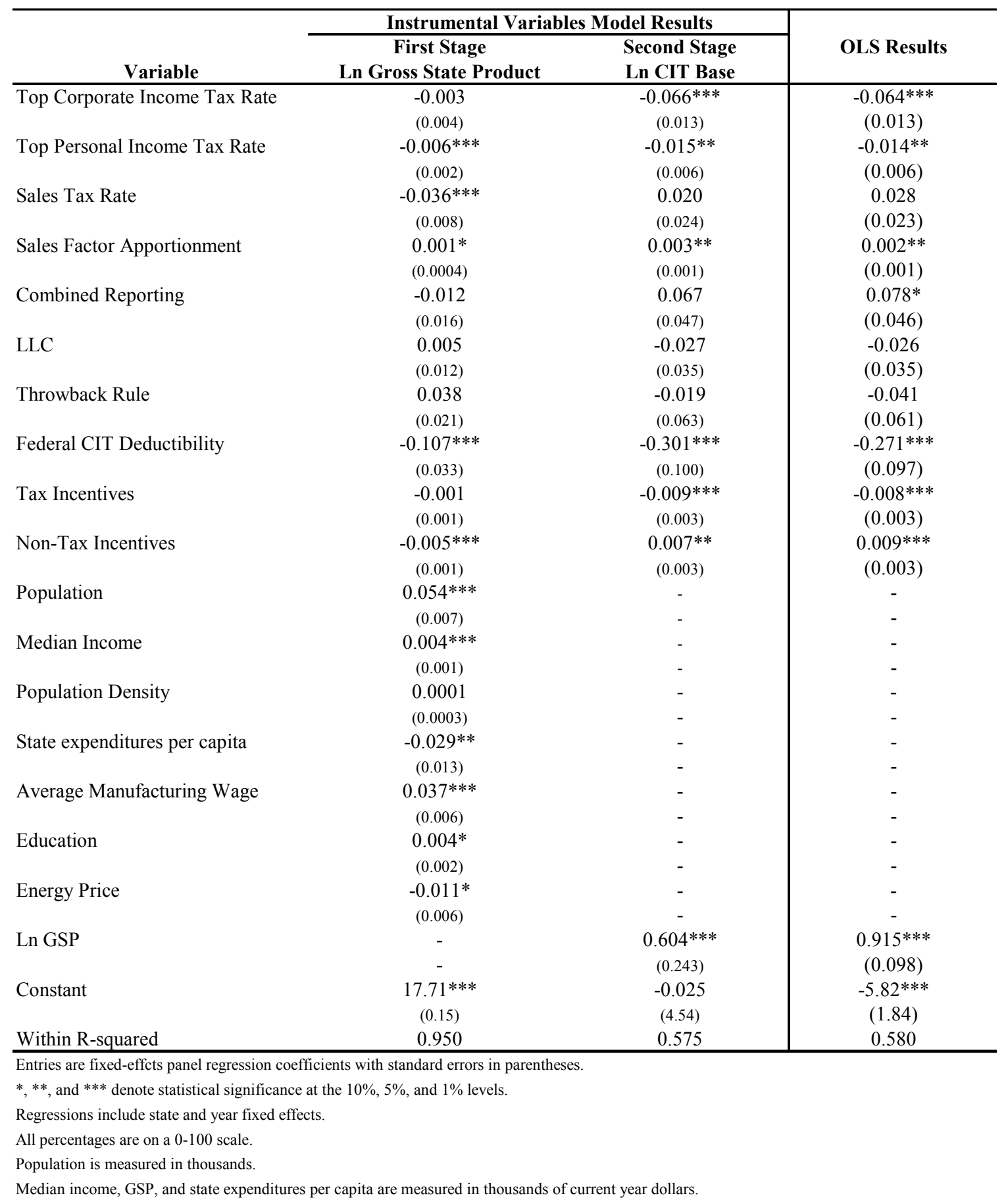


Table 2: Results with CIT Rate Interactions

\begin{tabular}{|c|c|c|}
\hline Variable & $\begin{array}{c}\text { First Stage } \\
\text { Ln Gross State Product }\end{array}$ & $\begin{array}{l}\text { Second Stage } \\
\text { Ln CIT Base }\end{array}$ \\
\hline \multirow[t]{2}{*}{ Top Corporate Income Tax Rate } & $0.028^{* *}$ & -0.016 \\
\hline & $(0.013)$ & $(0.040)$ \\
\hline \multirow[t]{2}{*}{ Top Personal Income Tax Rate } & $-0.007 * * *$ & $-0.015^{* *}$ \\
\hline & $(0.002)$ & $(0.007)$ \\
\hline \multirow[t]{2}{*}{ Sales Tax Rate } & $-0.045^{* * *}$ & 0.002 \\
\hline & $(0.008)$ & $(0.025)$ \\
\hline \multirow[t]{2}{*}{ Sales Factor Apportionment } & 0.002 & -0.002 \\
\hline & $(0.002)$ & $(0.006)$ \\
\hline \multirow[t]{2}{*}{ CIT Rate*Sales Apportionment } & -0.0003 & -0.0002 \\
\hline & $(0.0003)$ & $(0.001)$ \\
\hline \multirow[t]{2}{*}{ Combined Reporting } & $0.230 * *$ & $0.670 * *$ \\
\hline & $(0.095)$ & $(0.300)$ \\
\hline \multirow[t]{2}{*}{ CIT Rate*Combined Reporting } & -0.0004 & -0.030 \\
\hline & $(0.007)$ & $(0.020)$ \\
\hline \multirow[t]{2}{*}{ LLC } & $0.075 * * *$ & -0.030 \\
\hline & $(0.016)$ & $(0.052)$ \\
\hline \multirow[t]{2}{*}{ CIT Rate*LLC } & $-0.011 * * *$ & 0.002 \\
\hline & $(0.002)$ & $(0.006)$ \\
\hline \multirow[t]{2}{*}{ Throwback Rule } & $0.135^{*}$ & 0.336 \\
\hline & $(0.072)$ & $(0.226)$ \\
\hline \multirow[t]{2}{*}{ CIT Rate*Throwback Rule } & $-0.020 * * *$ & $-0.071 * * *$ \\
\hline & $(0.009)$ & $(0.027)$ \\
\hline \multirow[t]{2}{*}{ Combined Reporting*Sales Appt } & -0.001 & -0.0004 \\
\hline & $(0.001)$ & $(0.003)$ \\
\hline \multirow[t]{2}{*}{ Throwback Rule*Sales Appt } & $0.002 * * *$ & $0.006^{*}$ \\
\hline & $(0.001)$ & $(0.003)$ \\
\hline \multirow[t]{2}{*}{ Combined Reporting*Throwback Rule } & $-0.190 * * *$ & $-0.376^{* *}$ \\
\hline & $(0.053)$ & $(0.172)$ \\
\hline \multirow[t]{2}{*}{ Federal CIT Deductibilty } & $-0.093 * * *$ & -0.148 \\
\hline & $(0.035)$ & $(0.108)$ \\
\hline \multirow[t]{2}{*}{ Tax Incentives } & 0.0001 & $-0.007 * *$ \\
\hline & $(0.001)$ & $(0.003)$ \\
\hline \multirow[t]{2}{*}{ Non-Tax Incentives } & $-0.004 * * *$ & $0.007 * *$ \\
\hline & $(0.001)$ & $(0.003)$ \\
\hline \multirow[t]{2}{*}{ Population } & $0.047 * * *$ & - \\
\hline & $(0.006)$ & - \\
\hline Median Income & $0.004 * * *$ & - \\
\hline & $(0.001)$ & - \\
\hline Population Density & 0.0010 & - \\
\hline & $(0.0003)$ & - \\
\hline State expenditures per capita & -0.013 & - \\
\hline & $(0.013)$ & - \\
\hline Average Wage & $0.034 * * *$ & - \\
\hline & $(0.006)$ & - \\
\hline Education & $0.004 * *$ & - \\
\hline & $(0.002)$ & - \\
\hline Energy Price & $-0.011 *$ & - \\
\hline & $(0.006)$ & - \\
\hline Ln GSP & - & $0.444 *$ \\
\hline & - & $(0.252)$ \\
\hline Constant & $17.44 * * *$ & 2.75 \\
\hline & $(0.16)$ & (4.68) \\
\hline Within R-squared & 0.954 & 0.580 \\
\hline Entries are fixed-effcts panel regression coefficier & ith standard errors in parentheses. & \\
\hline$*, * *$, and ${ }^{* * *}$ denote statistical significance at th & $6,5 \%$, and $1 \%$ levels. & \\
\hline Regressions include state and year fixed effects. & & \\
\hline All percentages are on a $0-100$ scale. & & \\
\hline Population is measured in thousands. & & \\
\hline
\end{tabular}


Table 3: Results with CIT Rate Interacted with Time

\begin{tabular}{|c|c|c|}
\hline $\begin{array}{c}\text { Variable } \\
\end{array}$ & $\begin{array}{c}\text { First Stage } \\
\text { Ln Gross State Product } \\
\end{array}$ & $\begin{array}{l}\text { Second Stage } \\
\text { Ln CIT Base } \\
\end{array}$ \\
\hline \multirow[t]{2}{*}{ Top Corporate Income Tax Rate } & 0.005 & $-0.071 * * *$ \\
\hline & $(0.005)$ & $(0.014)$ \\
\hline \multirow[t]{2}{*}{ Top Personal Income Tax Rate } & $-0.008 * * *$ & $-0.016 * *$ \\
\hline & $(0.002)$ & $(0.007)$ \\
\hline \multirow[t]{2}{*}{ Sales Tax Rate } & $-0.035 * * *$ & 0.028 \\
\hline & $(0.008)$ & $(0.025)$ \\
\hline \multirow[t]{2}{*}{ Sales Factor Apportionment } & $0.001 * *$ & $0.002 *$ \\
\hline & $(0.0004)$ & $(0.001)$ \\
\hline \multirow[t]{2}{*}{ Combined Reporting } & 0.010 & $0.089 *$ \\
\hline & $(0.016)$ & $(0.048)$ \\
\hline \multirow[t]{2}{*}{ LLC } & $0.021 * *$ & $0.052 *$ \\
\hline & $(0.010)$ & $(0.031)$ \\
\hline \multirow[t]{2}{*}{ Throwback Rule } & $0.034 *$ & -0.032 \\
\hline & $(0.020)$ & $(0.065)$ \\
\hline \multirow[t]{2}{*}{ Federal CIT Deductibility } & $-0.121 * * *$ & $-0.264 * *$ \\
\hline & $(0.033)$ & $(0.104)$ \\
\hline \multirow[t]{2}{*}{ Tax Incentives } & 0.0001 & $-0.011 * * *$ \\
\hline & $(0.001)$ & $(0.003)$ \\
\hline \multirow[t]{2}{*}{ Non-Tax Incentives } & $-0.005 * * *$ & $0.008 * * *$ \\
\hline & $(0.001)$ & $(0.003)$ \\
\hline \multirow[t]{2}{*}{ Population } & $0.043 * * *$ & - \\
\hline & $(0.006)$ & - \\
\hline \multirow[t]{2}{*}{ Median Income } & $0.003 * *$ & - \\
\hline & $(0.001)$ & - \\
\hline \multirow[t]{2}{*}{ Population Density } & $0.001 *$ & - \\
\hline & $(0.0003)$ & - \\
\hline \multirow[t]{2}{*}{ State expenditures per capita } & -0.014 & - \\
\hline & $(0.013)$ & - \\
\hline \multirow[t]{2}{*}{ Average Wage } & $0.026 * * *$ & - \\
\hline & $(0.006)$ & - \\
\hline \multirow[t]{2}{*}{ Education } & $0.004 * *$ & - \\
\hline & $(0.002)$ & - \\
\hline \multirow[t]{2}{*}{ Energy Price } & $-0.009 * *$ & - \\
\hline & $(0.004)$ & - \\
\hline \multirow[t]{2}{*}{ Ln GSP } & - & $0.662 * *$ \\
\hline & - & $(0.284)$ \\
\hline \multirow[t]{2}{*}{ CIT Rate*Time Trend } & $-0.001 * * *$ & 0.0004 \\
\hline & $(0.0002)$ & $(0.001)$ \\
\hline \multirow[t]{2}{*}{ Time Trend } & $0.049 * * *$ & -0.015 \\
\hline & $(0.003)$ & $(0.020)$ \\
\hline \multirow[t]{2}{*}{ Constant } & $17.10 * * *$ & -0.84 \\
\hline & $(0.09)$ & $(5.02)$ \\
\hline Within R-squared & 0.950 & 0.536 \\
\hline
\end{tabular}

Entries are fixed-effcts panel regression coefficients with standard errors in parentheses.

$*{ }^{* *}$, and $* * *$ denote statistical significance at the $10 \%, 5 \%$, and $1 \%$ levels.

Regressions include state fixed effects.

All percentages are on a 0-100 scale.

Population is measured in thousands.

Median income, GSP, and state expenditures per capita are measured in thousands of current year dollars. 
Appendix 1: Summary Statistics

\begin{tabular}{lcccc}
\hline & \multicolumn{2}{c}{$\mathbf{1 9 8 5}$} & \multicolumn{2}{c}{$\mathbf{2 0 0 1}$} \\
& Mean & Std.Dev. & Mean & Std.Dev. \\
\hline Non-Government Gross State Product (millions) & 72,000 & 87,300 & 178,000 & 217,000 \\
Corporate Income Tax Collections (thousands) & 265,564 & 334,276 & 590,840 & $1,091,370$ \\
\hline Top Corporate Income Tax Rate & 6.5 & 3.2 & 6.6 & 2.9 \\
Top Personal Income Tax Rate & 6.9 & 4.9 & 5.6 & 3.2 \\
Sales Tax Rate & 4.1 & 1.7 & 4.6 & 1.8 \\
\hline Sales Factor Apportionment & 32.6 & 16.1 & 42.2 & 22.6 \\
Combined Reporting & 0.18 & 0.39 & 0.28 & 0.45 \\
Throwback Rule & 0.49 & 0.50 & 0.46 & 0.50 \\
LLC & 0 & 0 & 1 & 0 \\
Federal CIT Deductibility & 0.09 & 0.28 & 0.06 & 0.22 \\
Tax Incentives & 10.2 & 1.9 & 8.6 & 6.1 \\
Non-tax Incentives & 4.7 & 2.7 & 12.56 & 7.99 \\
\hline Population (thousands) & 4,745 & 5,068 & 5,694 & 6,300 \\
Median Income (thousands) & 32.0 & 4.0 & 62.0 & 9.0 \\
Population Density & 160 & 228 & 184 & 253 \\
State expenditures per capita (thousands) & 1.8 & 1.1 & 4.3 & 1.2 \\
Average Wage & 9.4 & 1.2 & 14.5 & 1.6 \\
Education & 18.5 & 3.6 & 25.4 & 4.3 \\
Energy Price & 8.5 & 1.1 & 10.0 & 1.6 \\
\hline Nit Al & & & & \\
\hline
\end{tabular}

Notes: All percentages are on a 0-100 scale.

All dollar amounts are expressed as current year dollars. 


\section{Appendix 2: Data Descriptions and Source Notes}

\begin{tabular}{|l|l|}
\hline \multicolumn{1}{|c|}{ Variable } & \multicolumn{1}{|c|}{ Definition } \\
\hline Non-Government Gross State Product & Total Gross state product less GSP from government sector. (1) \\
\hline Corporate Income Tax Base & Corporate income tax (CIT) revenues divided by top marginal CIT rate. (2) \\
\hline Top Corporate Income Tax Rate & Highest marginal corporate income tax rate. (3) \\
\hline Top Personal Income Tax Rate & Highest marginal personal income tax rate. (3) \\
\hline Sales Tax Rate & General sales tax rate. (3) \\
\hline Sales Factor Apportionment & Weight given to sales factor in the corporate income tax apportionment formula. (3) \\
\hline Combined Reporting & 1 if a state has a combined reporting requirement. (3) \\
\hline Throwback Rule & 1 if a state has a throwback rule. (4) \\
\hline LLC & 1 if a state allows LLCs. (5) \\
\hline Federal CIT Deductibility & 1 if a state allows deduction of federal CIT liability from state CIT liability. (12) \\
\hline Tax Incentives & Number of tax incentive programs a state offers. (6) \\
\hline Non-Tax Incentives & Number of non-tax incentive programs a state offers. (6) \\
\hline Population (thousands) & State population. (7) \\
\hline Median Income (thousands) & State median income. (7) \\
\hline Population Density & Population/square miles in a state. (8) \\
\hline State expenditures per capita (thousands) & State government expenditures/population. (9) \\
\hline Average Wage & Average hourly wage for manufacturing workers. (10) \\
\hline Education & Percent of population over age 25 that hold at least a Bachelor's degree. (7) \\
\hline Energy Price & Estimate of energy costs for all forms of energy, measured per million Btu. (11) \\
\hline
\end{tabular}

Source Notes:

1. Regional Economic Accounts, Bureau of Economic Analysis, various years.

2. Author's calculations based on data from State Government Finances, U.S. Census Bureau, various years, and State Tax Handbook, Commerce Clearing House, various years.

3. State Tax Handbook, Commerce Clearing House, various years.

4. State Tax Handbook, Commerce Clearing House (various years) and various state revenue departments.

5. www.llcweb.com

6. National Association of State Development Agencies, various years.

7. Statistical Abstract of the United States, U.S. Census Bureau, various years.

8. Author's calculations based on data from Statistical Abstract of the United States, U.S. Census Bureau, various years.

9. Author's calculations based on data from State Government Finances, U.S. Census Bureau, various years.

10. Employment and Wages, U.S. Bureau of Labor Statistics, various years.

11. Energy Price Estimates by Source, U.S. Department of Energy, various years.

12. We thank Justin Garosi for assembiling these data from primary sources. 